\title{
Permainan Tradisional Anak-Anak Meningkatkan Hasil Belajar Kompetensi Gerak Dasar Lari Siswa Kelas I SD Negeri Bonangrejo Semester 1 Tahun Pelajaran 2015/2016 \\ (Improving The First Year Students' Basic Running Movement Achievement of SDN Bonangrejo in The Academic Year of 2015/2016)
}

Jaka Sutrisna

SDN Bonangrejo Bonang, Demak

\begin{abstract}
Abstrak
Pembelajaran atletik khususnya di SDN Bonangrejo masih belum mendapatkan hasil akhir yang memuaskan khususnya pada materi gerakan dasar lari. Hal ini terjadi karena siswa kurang tertarik dengan pelajaran penjasorkes meskipun banyak siswa yang merasa senang dengan pelajaran tersebut. Untuk mengatasinya peneliti menerapkan metode permainan buka tutup dan permainan sapu tangan serta dikolaborasikan dengan materi gerak dasar lari. Hasil prestasi siswa prasiklus hanya 12 siswa atau sekitar 29\% dari 41 siswa yang mecapai KKM (70), pada siklus I mengalami peningkatan menjadi 23 siswa atau 56\%. Pada siklus II hasil belajar gerak dasar lari meningkat sebanyak 38 siswa atau 92\%. Sehingga hanya 3 siswa atau 7\% saja yang belum memenuhi KKM. Dengan demikian, penelitian tindakan kelas pada siswa kelas 1 SD Negeri Bonangrejo Bonang Demak dalam upaya meningkatkan hasil belajar gerak dasar lari menggunakan metode pembelajaran yang dikolaborasi degan permainan tradisional anak-anak telah mencapai keberhasilan meningkatkan hasil belajar gerak dasar lari.
\end{abstract}

Kata Kunci : gerak dasar lari, permainan tradisioanal

Abstract

Learning athletics, especially in SDN Bonangrejo still not getting satisfactory final result, especially on the basis of material movement run. This happens because students are less interested in the lessons penjasorkes although many students who feel happy with the lesson. To overcome the researchers applied the method unscrew the game and the game handkerchief and collaborated with the basic motion of matter run. The results of student achievement prasiklus only 12 students, or about $29 \%$ of the 41 students who mecapai KKM (70), the first cycle increased to 23 students or $56 \%$. In the second cycle of learning outcomes run the basic motion increased by 38 students or $92 \%$. So that only 3 students or $7 \%$ that do not meet the KKM. Thus, action research in Class I SD Negeri Bonangrejo Bonang Demak in an effort to improve learning outcomes run the basic motion using methods that collaborated degan traditional games children have achieved success improve learning outcomes of basic motion run.

Keywords : basic motion run, tradisional game

\section{Pendahuluan}

Salah satu pelajaran olahraga di kelas 1 adalah atletik, namun dalam pelaksanaan yang sesungguhnya baru bersifat pengenalan. Pada pelajaran atletik yang dipelajari siswa kelas I adalah Gerak Dasar Lari. Sehingga guru penjas harus menggunakan metode yang tepat guna menerapkan pada kegiatan belajar mengajar. Meskipun siswa pada saat kegiatan pembelajaran tidak mengetahui tentang apa yang telah dilaksanakan namun siswa merasa senang dan nyaman dalam melakukan kegiatan apa yang diperintah oleh guru.

Penggunaan metode pembelajaran yang tepat dimungkinkan dapat mencapai tujuan pembelajaran yang sudah direncanakan sebelumnya. Guru menggunakan metode bermain, maka dalam pembelajaran pada materi Gerak Dasar Lari guru mengkolaborasi dengan permainan tradisional anak-anak. Siswa dalam mempelajari materi tersebut dikenalkan dengan cara bermain, sehingga siswa belajar atletik secara tidak langsung. Jenis permainan yang digunakan dalam kegiatan pembelajaran ini yaitu permainan buka tutup dan permainan sapu tangan. Dengan permainan tradisional anak-anak ini siswa diharapkan dapat meningkatkan aktivitas dalam kegiatan pembelajaran dan memperoleh hasil belajar di atas KKM yang telah ditentukan.

Yang akan dibahas dalam penelitian ini adalah meningkatkan hasil belajar kompetensi gerak dasar lari menggunakan metode permainan tradisional anak-anak pada siswa kelas I SD Negeri Bonangrejo Semester 1 Tahun Pelajaran 2015/2016.

Tujuan penelitian ini adalah meningkatkan hasil belajar siswa pada mata pelajaran Pendidikan Jasmani (Penjas) kompetensi gerak dasar lari melalui permainan tradisional anak-anak disamping itu mendeskripsikan penerapan permainan tradisional anak-anak untuk meningkatkan hasil belajar Pendidikan Jasmani (Penjas) kompetensi gerak dasar lari pada siswa KelasI SD Negeri Bonangrejo Kecamatan Bonang Kabupaten Demak Semester I Tahun Ajaran 2015/2016.

\section{Metode Penelitian}

Subjek penelitian adalah siswa kelas 1 SD Negeri 
Bonangrejo dengan jumlah siswa 41 orang yang terdiri dari 20 orang siswa laki-laki dan 21 orang siswa perempuan. Pelaksanaan penelitan dilaksanakan dari 12 Agustus hingga 16 September 2016.

Penelitian ini menggunakan penelitian tindakan kelas yang menyatakan bahwa pengamatan dan tindakan merupakan suatu peristiwa yang simultan. Siklus yang akan dipergunakan dalam penelitian ini ada dua siklus dan masing-masing siklus mengikuti tahapan perencanaa (planning) pelaksanaan tindakan (action), pengamatan (observation) dan refleksi.

\section{Hasil Penelitian}

Kondisi awal merupakan hasil tes dalam penelitian yang belum menggunakan metode maupun teknik yang akan dilakukan dalam penelitian. Hasil yang diperoleh pada kondisi awal yaitu siswa yang memperoleh nilai kurang dari 49 ada 7 anak, memperoleh nilai 50-59 ada 9 anak, memperoleh nilai 60-69 ada 13 anak, memperoleh nilai 7079 ada 6 anak, sedangkan siswa yang memperoleh nilai 8089 ada 6 anak.

Pelaksanaan siklus I berlangsung selama dua kali pertemuan ( $2 \times 35$ menit), yaitu pada hari Rabu tanggal 26 Agustus 2015 dan 4 September 2015 di halaman sekolah SD Negeri Bonangrejo Bonang Demak. Siklus I dimulai pada hari Rabu tanggal 27 Agustus 2015 saat jam pelajaran ke-2 dan ke-3. Pelaksanaan diambil pada jam ke-2 dan ke-3 dkarenakan pada jam ke-1 digunakan untuk persiapan pelaksanaan penelitian. Siklus I dilanjutkan pada pertemuan kedua, yaitu hari Rabu, 4 September 2015, pada jam pelajaran ke-2 dan ke-3.

Perbandingan hasil yang diperoleh pada kondisi awal dengan siklus I yaitu siswa yang memperoleh nilai kurang dari 49 ada 7 anak menjadi 1 anak, memperoleh nilai 50-59 ada 9 anak menjadi 9 anak, memperoleh nilai 60-69 ada 13 anak menjadi 9 anak, memperoleh nilai $70-79$ ada 6 anak menjadi 16 anak, sedangkan siswa yâng memperoleh nilai 80-89 ada 6 anak menjadi 7 anak. Dari uraian tersebut dapat kita lihat adanya peningkatan dari kondisi awal ke siklus I.

Tindakan II dilaksanakan pada hari Rabu tanggal 16 September 2015 dan tanggal 23 September 2015, dalam dua jam pelajaran (jam pelajaran ke-2 dan ke-3) yang berdurasi 2 × 35 menit di halaman sekolah SD Negeri Bonangrejo Bonang Demak.

Perbandingn hasil belajar pada siklus II yang diperoleh pada kondisi awal, siklus I, dan siklus II yaitu siswa yang memperoleh nilai kurang dari 49 yaitu 7:1:0, memperoleh nilai 50-59 yaitu 9:9:0, memperoleh nilai 60-69 yaitu 13:9:3, memperoleh nilai 70-79 yaitu 6:16:15, sedangkan siswa yang memperoleh nilai 80-89 yaitu 6:7:23. Dari uaraian tersebut dapat kita lihat adanya peningkatan dari kondisi awal ke siklus I kemudian meningkat tajam pada siklus II.

Keberhasilan penerapan metode pembelajaran tentang permainan tradisional anak-anak dapat meningkatkan kualitas proses dan hasil belajar gerak dasar lari dapat dilihat dari indikator-indikator di bawah ini.

1. Motivasi mengikuti pembelajaran gerak dasar lari meningkat.
Penerapan metode pembelajaranyang dikolaborasi dengan permainan tradisional anak-anak mampu meningkatkan motivasi pembelajaran gerak dasar lari pada siswa kelas 1 SD Negeri Bonangrejo Bonang Demak. Peningkatan dari segi motivasi dalam pembelajaran dapat dilihat pada indikator berikut ini:

a. Meningkatnya keaktifan siswa

Penggunaan media pembelajaran yang dimodifikasi dalam pembelajaran gerak dasar lari jarak pendek dapat meningkatkan kualitas kegiatan belajar mengajar. Dengan memanfaatkan media pembelajaran berarti guru melakukan usaha untuk membuat proses pembelajaran menjadi menyenangkan. Guru memancing siswa untuk aktif dan memberikan kesempatan seluas-luasnnya bagi siswa untuk bertanya tentang kejelasan materi ataupun kesulitan yang dihadapi siswa ketika mengikuti proses pembelajaran.

b. Meningkatnya perhatian siswa

Perhatian siswa terhadap penjelasan guru sangatlah penting. Perhatian ini akan turut menentukan tingkat pemahaman siswa terhadap materi yang dijelaskan oleh guru. Dalam hal ini guru harus mampu memunculkan sesuatu yang baru, unik,dan inovatif dalam pembelajaran, termasuk di dalamnya adalah pemilihan metode pembelajaran yang kreatif dan menyenangkan.

c. Meningkatnya keterampilan guru dalam mengelola kelas

Dengan adanya penelitian ini membuat guru semakin piawai dalam memimpin siswa. Pengelolaan kelas pad pelaksanaan tindakan I dan II jauh lebih baik dibandingkan dengan pengelolaan pada pratindakan. Sedikit demi sedikit kelemahan guru berkurang karena setiap akhir siklus peneliti dan guru sejawat melakukan analisis dan refleksi kegiatan pembelajaran. Jika terdapat kekurangan dalam siklus yang bersangkutan,pada pelaksanaan tindakan selanjutnya akan dicarikansolusi pemecahan dan meminimalkan kekurangan tersebut sehingga kekurangan dalam pelaksanaan pembelajaran yang dilakukan oleh guru dapat teratasi dan tidak akan terulang kembali.

2. Hasil pembelajaran gerak dasar lari meningkat

Dalam melaksanakan pembelajaran guru harus mau mendengarkan saran dan keluhan dari siswa. Saran dan keluhan ini pada akhirnya dapat menjadi masukan bagi guru untuk mendapatkan hasil yang lebih baik pada pembelajaran selanjutnya. Contoh konkritnya dapat dilihat pada akhir penelitian ini. Peningkatan kualitas hasil dapat dilihat dari hasil belajar siswa yang mengalami peningkatan dari sebelum tindakan hingga akhir siklus terakhir, dalam penelitian ini adalah akhir siklus II. Sebelum pelaksanaan tindakan, siswa yang berhasil mencapai batas ketuntasan nilai pada angka 70 untuk hasil rangkaian gerak dasar lari sebanyak 12 siswa atau sekitar 29\%, Selanjutnya mengalami peningkatan pada siklus I, yaitu untuk hasil tes praktik gerak dasar lari menjadi $80 \%$ atau sekitar 33 siswa telah mencapai indikator target capaian pada siklus I.

Titik puncak peningkatan hasil belajar gerak dasar lari pada penelitian ini adalah pada siklus II. Pada siklus II ini hasil belajar gerak dasar lari menunjukkan bahwa nilai siswa telah mencapai indikator keberhasilan yang telah ditetapkan. Dengan demikian, penelitian tindakan kelas pada siswa kelas 1 SDN Bonangrejo dalam upaya meningkatkan hasil belajar 
gerak dasar lari menggunakan metode pembelajaran yang dikolaborasi ini telah mencapai keberhasilan pada pelaksanaan siklus kedua. Dengan tercapainya indikator keberhasilan, maka penelitian ini dapat dikatakan berhasil dan dapat dihentikan.

\section{Kesimpulan dan Saran}

Berdasarkan analisis data yang telah dilakukan dan pembahasan yang telah diungkapkan di atas, diperoleh simpulan permainan tradisional anak-anak dalam pembelajaran penjas dapat meningkatkan hasil belajar gerak dasar lari pada dalam pembelajaran penjas dapat meningkatkan hasil belajar gerak dasar lari siswa Kelas I SD Negeri Bonangrejo Kecamatan Bonang Kabupaten Demak. Permainan tradisional anak-anak dapat diterapkan dalam pembelajaran penjas kompetensi gerak dasar lari pada Siswa Kelas I SD Negeri Bonangrejo Kecamatan Bonang Kabupaten Demak Semester I Tahun Ajaran 2015/2016 diantaranya Peningkatan kualitas hasil dapat dilihat dari hasil belajar siswa yang mengalami peningkatan dari sebelum tindakan hingga akhir siklus terakhir, dalam penelitian ini adalah akhir siklus II. Sebelum pelaksanaan tindakan, siswa yang berhasil mencapai kriteria ketuntasan minimal (KKM) untuk hasil rangkaian tes gerak dasar lari sebanyak 12 siswa atau sekitar 29\%, Selanjutnya mengalami peningkatan pada siklus $\mathrm{I}$, yaitu untuk hasil tes gerak dasar lari menjadi $80 \%$ atau sekitar 33 siswa. Titik puncak peningkatan hasil belajar gerak dasar lari jarak pendek pada penelitian ini adalah pada siklus II. Pada siklus II ini hasil belajar gerak dasar lari jarak pendek menunjukkan bahwa nilai siswa telah KKM. Siswa yang mampu melakukan gerak dasar lari jarak pendek dengan baik atau telah mencapai batas ketuntasan untuk hasil belajar gerak dasar lari jarak pendek sebanyak 38 siswa atau sekitar $92 \%$ siswa. Dengan demikian, penelitian tindakan kelas pada siswa kelas $1 \mathrm{SD}$ Negeri Bonangrejo Bonang Demak dalam upaya meningkatkan hasil belajar gerak dasar lari menggunakan metode pembelajaran yang dikolaborasi degan permainan tradisional anak-anak telah mencapai keberhasilan meningkatkan hasil belajar gerak dasar lari.

Pemberian tindakan dari siklus I, dan II memberikan deskripsi bahwa terdapatnya kekurangan atau kelemahan yang terjadi selama proses pembelajaran berlangsung. Namun, kekurangan-kekurangan tersebut dapat di atasi pada pelaksanaan tindakan pada siklus-siklus berikutnya.

Beberapa saran yang perlu kita perhatikan antara lain guru hendaknya memastikan siswa telah benar-benar memahami materi sebelum memberikan tugas. Guru jangan sampai lupa memberikan contoh secara langsung dan jelas agar siswa lebih mudah memahami materi yang diajarkan. Dalam mengajar mengajar hendaknya guru lebih terbuka dengan saran-saran yang diberikan oleh siswa demi terciptanya pembelajaran yang menyenangkan dan menarik bagi siswa sehingga siswa dapat termotivasi untuk mengikuti pembelajaran dengan semaksimal mungkin. Guru hendaknya mengoptimalkan berbagai bentuk metode pembelajaran, baik di dalam maupun di luar kelas sebagai penunjang pembelajaran gerak dasar lari jarak pendek pada mata pelajaran penjasorkes.

\section{Ucapan Terima Kasih}

Kami mengucapkan terima kasih kepada semua pihak yang telah membantu penyusunan laporan ini, secara khusus saya sampaikan terima kasih kepada Dra. Sri Rahayuningsih, M.H, M.P.d. selaku Kepala UPTD Dikpora Kecamatan Bonang, rekan guru dan siswa SD Negeri Bonangrejo, dan semua pihak yang membantu dalam penyelesaian tulisan ini baik secara moril maupun materiil

\section{Daftar Pustaka}

[1] Badan Standar Nasional Pendidikan. Permendiknas RI No. 22 tahun 2006 tentang Standar Isi untuk Satuan Dikdasmen. Jakarta. (2006)

[2] Direktorat Permuseuman. Permainan Tradisional Indonesia. Jakarta: Proyek Pembinaan Permuseuman Azhar, Arsyad. (2002). Media Pendidikan. Jakarta. PT Raja Grafindo Persada. (1998).

[3] Bahagia Y \& Suherman A. Prinsip-Prinsip Pengembangan dan Modifikasi Cabang Olahraga. Jakarta: Depdikbud. Direktorat Jenderal Pendidikan Dasar Dan Menengah Bagian Proyek Penataran Guru SLTP Setara D-III. (2000).

[4] Dimyati dan Mudjiono. Belajar dan Pembelajaran. Jakarta: PT.Rineka Cipta. (2009).

5] Djamarah, \& Bahri S. Psikologi Belajar. Cet.I. Jakarta: RinekaCipta. (2002).

[6] Huda, Miftahul. Model-model Pengajaran dan Pembelajaran. Isuisu Metodis danParadigmatis. Yogjakarta: Pustaka Pelajar. (2015).

[7] Kristiyanto, A.PenelitianTindakan Kelas (PTK) Dalam Pendidikan Jasmani dan Kepelatihan Olahraga. Surakarta: UNS Press. (2010).

[8] Purwanto, Ngalim. Psikologi Pendidikan. Bandung: Rosdakarya. (2006).

Purnomo, E.\& Dapan. Dasar-Dasar Gerak Atletik. Yogyakarta: Alfamedia. (2011)

[10] Rusman, Kurniawan D, Riyana C. Pembelajaran Berbasis Teknologi Informasi dan Komunikasi. Jakarta: Raja Gratindo Persada. (2011).

[11] Sanjaya W. Perencanaan dan Desain Sistem Pembelajaran. Jakarta: Prenada Media Group. (2006).

12] Syarifuddin, A.dan Muhadi. Pendidikan Jasmani dan Kesehatan. Jakarta: Depdikbud. Dirkendikti. Proyek Pembinaan Tenaga Kependidikan. (1992).

[13] Suharno HP. Metodologi Pelatihan. Yogyakarta : IKIP Yogyakarta. (1993).

[14] Sukintaka. Teori Pendidikan Jasmani Filosofi Pembelajaran dan Masa Depan. Bandung: Yayasan Nuansa Cendekia. (2004).

15] Sukirman, D. Permainan Tradisional Jawa, Yogyakarta : Kepel Press (2005).

[16] Surya, Mohammad. Psikologi Pendidikan (Cetakan ke-5 Edisi Revisi). Bandung: Jurusan PPB UPI. (1992).

[17] Waharsono. Materi Pelatihan Guru Pendidikan Jasmani dan Kesehatan SD/Pelatih Klub Olahraga Usia Dini. Jakarta: Depdikbud. Direktorat Pendidikan Dasar. (1999).

[18] Widya, M.D.A. Gerak-Gerak Dasar Atletik Dalam Bermain. Jakarta: PT Rajagrafindo Persada. (2007). 